\title{
Article
}

\section{Aspects of Energy Saving of Oil-Producing Enterprises}

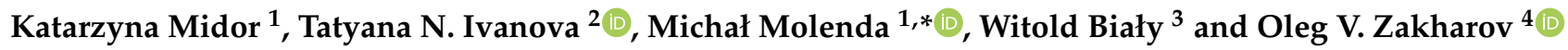 \\ 1 Faculty of Organization and Management, Silesian University of Technology, 41-800 Zabrze, Poland; \\ katarzyna.midor@polsl.pl \\ 2 Tchaikovsky Branch "Perm National Research Polytechnic Institute”, 617764 Tchaikovsky, 426000 Izhevsk, Russia; \\ tatnic2013@yandex.ru \\ 3 KOMAG Institute of Mining Technology, 44-101 Gliwice, Poland; witoldbialy@poczta.onet.pl \\ 4 Department Technology of Mechanical Engineering, Yuri Gagarin State Technical University of Saratov, \\ 410054 Saratov, Russia; zov20@mail.ru \\ * Correspondence: michal.molenda@polsl.pl
}

Citation: Midor, K.; Ivanova, T.N.; Molenda, M.; Biały, W.; Zakharov, O.V. Aspects of Energy Saving of Oil-Producing Enterprises. Energies 2022, 15, 259. https://doi.org/ $10.3390 /$ en15010259

Academic Editor: Wieslaw Urban

Received: 16 November 2021

Accepted: 27 December 2021

Published: 31 December 2021

Publisher's Note: MDPI stays neutral with regard to jurisdictional claims in published maps and institutional affiliations.

Copyright: (c) 2021 by the authors Licensee MDPI, Basel, Switzerland. This article is an open access article distributed under the terms and conditions of the Creative Commons Attribution (CC BY) license (https:// creativecommons.org/licenses/by/ $4.0 /)$.

\begin{abstract}
Increasing energy efficiency is included in the UN Sustainable Development Goals (SDGs) to be achieved by the year 2030. Enhancing energy efficiency is also one of the priority areas for improving the operational efficiency of any oil production enterprise. The energy management system of enterprises has been founded and implemented on the basis of the international standard ISO 50001:2018 and it works successfully. The energy efficiency strategy is formulated in the energy policy and integrated into the business model of the companies. Companies receive significant energy savings in the exploration and production segments through technical, technological, and organizational measures. This article shows the main directions for improving the energy efficiency of the artificial lift well stock and the results of their implementation. The main constraints on the implementation of the energy efficiency policy of oil-producing enterprises have been identified and directions for improvement of energy-saving structure have been proposed. The article proposes strategic-level classification of energy-saving measures, which is based on assessment and comparison of implementation costs, payback period, and takes into account investments into artificial lift technology, therefore allowing investment priorities in the energy management sphere to be distinguished. Advanced directions for investment in oil-production technology have been identified, and an algorithm of development and implementation of key indicators of energy consumption efficiency has been proposed.
\end{abstract}

Keywords: energy efficiency; energy saving; recovery; oil; energy policy

\section{Introduction}

Saving electric energy resources and increasing the efficiency of their use are the key tasks of modern production. As proved by the statistics of the UN [1], the higher amount of energy consumed by one person, the better level of lifestyle that is reached, and up-to-date industrial technologies find wider use. When the energy is used inefficiently, the lifestyle level decreases directly proportional with the drop in a country's national income.

The issues of efficient use of energy during production, transformation, transportation, distribution and consumption refer to a special direction of the energy industry-energy saving [1]. The tool for providing efficient energy-saving is energy management, which combines information and analytical, organizational, technical and regulatory activities.

To solve practical tasks of a complex efficient use of energy, the enterprises are following the requirements of ISO 50001 [2-5]. Despite geographic, cultural and social conditions, the enterprises of any type and size are developing systems and processes for improvement of energy efficiency [6-8]. Successful implementation depends on liabilities taken at all levels and across all functional areas $[9,10]$. It is supposed that implementation of energy management would reduce the costs on energy by means of systematic control over energy 
sources. The standards set the requirements to the energy control system. Based on these requirements, an enterprise can develop and implement energy policy, set goals, tasks and develop plans of activities in accordance with legislative requirements and information connected with issues of considerable use of energy. An energy management system allows enterprises to fulfill their liabilities, formulated in the policy, take measures, which are necessary for improvement of energy efficiency, and demonstrate the correspondence of the system with requirements of the standards [11].

Energy management is based on the "continuous improvement cycle" methodology "Plan-Do-Check-Act" (PDCA) (Figure 1), which is described in the following way [11]:

- Planning (plan)—carrying out energy analysis and determination of basic criteria and parameters of energy efficiency, setting goals, tasks and development of plan of activities, which are necessary for improvement of energy efficiency according to the energy policy of the enterprise;

- Doing (do) - implementation of planned activities in the sphere of energy management;

- Checking (check) - monitoring and measurement of processes and key characteristics of operations, that determine energy performance in relation to the implementation of energy policy and the achievement of energy goals, and reporting the results;

- Action (act) - taking the measures for continuous improvement of efficiency of activities in the sphere of energy and the energy management system.

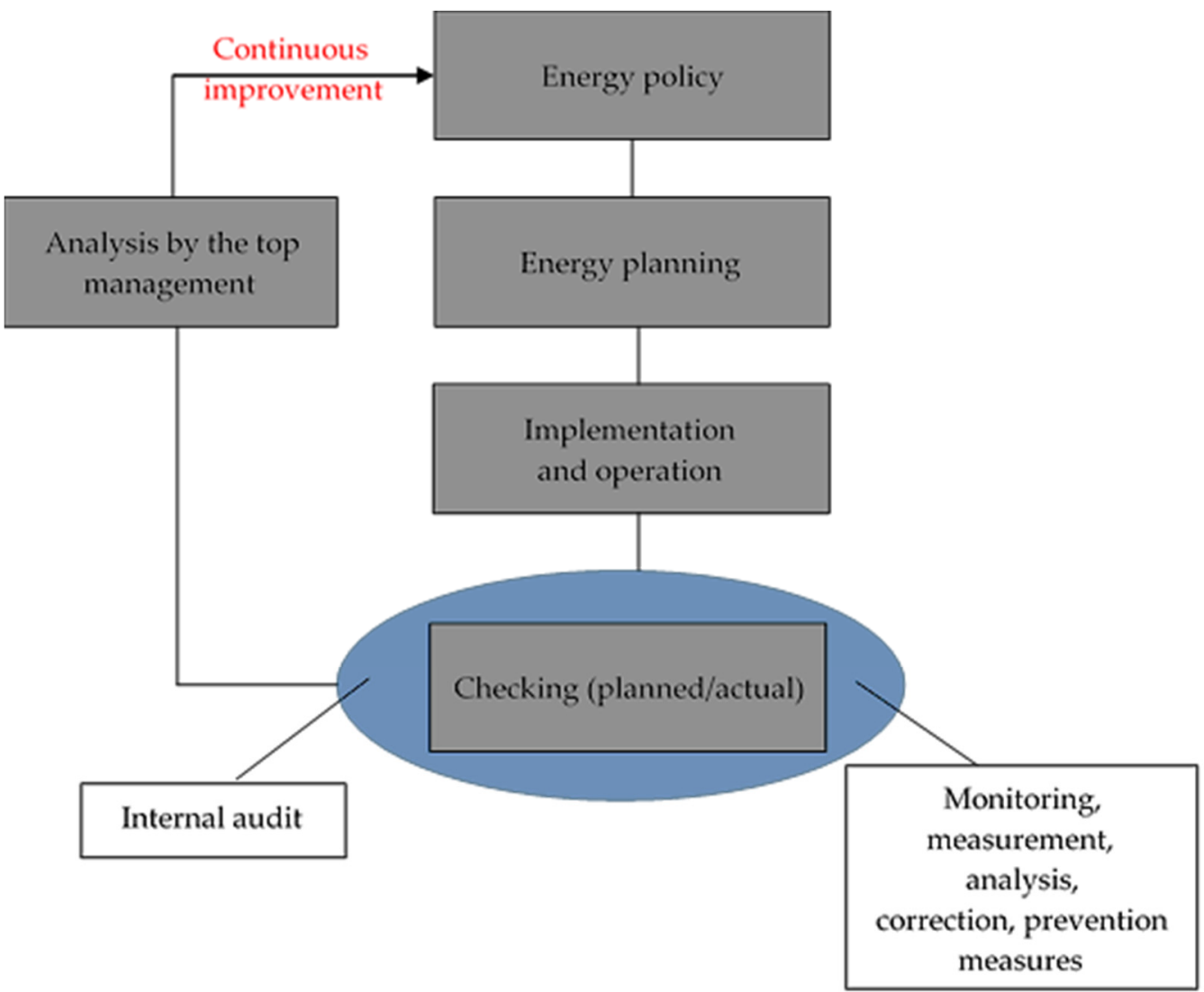

Figure 1. "Plan-Do-Check-Act" (PDCA) model.

A PDCA cycle-based methodology allows enterprises to develop systems and processes that are necessary for improvement of energy effectiveness, including the consumption and utilization of energy [12]. Implementation of this technology contributes to reducing the negative impact on the environment and lessens the energy costs due to systematic control of energy resources by a set of interrelated elements, which are used for development and implementation of energy-saving policy, its goals and processes aimed 
at reaching this. The methodology is also used for taking measures for improvement of energy effectiveness, demonstrating correspondence of energy system to the requirements of standards. That is why it is recommended to use the PDCA methodology, which is also known as the cycle of continuous improvement of processes, which incorporates all aspects of energy management into daily organizational practices.

\section{Literature Review}

The term energy effectiveness includes energy utilization, energy efficiency and energy consumption. Consequently, the enterprise, implementing an energy management system, can choose a course of action for itself from activities related to energy effectiveness. For example, it can decrease maximum load (maximum power need), use the extra energy or secondary energy resources, or improve operation of its energy system, processes and equipment [13-15]. Important conditions for the achievement of competitiveness of an enterprise are the development and introduction of practice-oriented methods for supporting managerial decisions that would make it possible to manage the energy efficiency of an enterprise as a social intellectual system [16].

Although the problem of energy consumption optimization is not new, it remains relevant [17-19]. Most researchers in the energy management sphere dedicate their work to issues of studying regional energy systems and large monopolies and problems of energy-efficient functioning of industrial systems [1-5,7,8,20-22].

There are typical energy consumption strategies, which can be used for strategic planning [23]:

- $\quad$ Passive strategy. Energy consumption management is not considered as a separate target. The tasks of energy policy development and application of international standards of energy management are auxiliary in searching for ways to survive for an enterprise in an environment of increased competition.

- $\quad$ Profit-maximizing strategy in short-term period. The directorship takes measures with small payback period and high rate of return, choosing well-known efficient standard solutions, the implementation of which does not require additional obstacles like additional training of employees or increasing the efficiency of introduction of new technologies.

- $\quad$ Profit-maximizing strategy in a long-term period. The directorship has solid understanding of market prices on energy sources and technology development, so it takes into consideration the projects with high payback periods of investments.

- $\quad$ Strategy of implementation of all attractive investment measures. The directorship takes all possible measures in the sphere of optimization of energy consumption, which have positive economic effect in short-term and long-term perspective.

Factors determining the success of projects on energy management, have greatly changed over the last few years; new tendencies of development of energy-saving technologies have appeared. The main difficulties that should be noted include: low incentives for investment in energy saving, long payback periods, limited funding, increased costs of energy audit services. Oil-production enterprises do not fully use cost optimization methods for energy-saving measures and energy inspection, they do not take into account employees' motivation, and they do not pay attention to design and process approaches for development of an efficient energy-saving management system. We think that the main aspect of increasing the energy efficiency of oil production enterprises is the organization of energy saving [24].

The purpose of the work is to substantiate and develop methodological support for the formation of an organizational mechanism for managing energy saving at an oilproduction enterprise.

\section{Materials and Methods}

Assessment of energy saving potential of industrial enterprise of any country begins with analysis of energy policy and energy consumption directions and structure. 
PJSC Rosneft is one of the biggest consumers of fuel and energy resources (FER) in the Russian Federation. The total volume of consumed FER for 2020 reached 18.9 million tons of fuel equivalent or 2749,33 million euros. Table 1 shows the distribution of energy consumption and energy costs in 2020 by areas of production [25].

Table 1. Distribution of energy consumption and energy costs in 2020 by areas of production activity.

\begin{tabular}{|c|c|c|c|c|c|}
\hline \multirow[b]{2}{*}{ Area of Activity } & \multicolumn{3}{|c|}{ Consumption of Fuel and Energy Resources } & \multirow{2}{*}{$\begin{array}{l}\text { Adjusted to thnd. } \\
\text { Tons of Fuel } \\
\text { Equivalent/mln } \\
\text { Euro. }\end{array}$} & \multirow[b]{2}{*}{$\begin{array}{c}\text { FER } \\
\text { Share, } \%\end{array}$} \\
\hline & $\begin{array}{l}\text { Electric Energy, } \\
\mathrm{MWh} / \mathrm{mln} \text { Euro }\end{array}$ & $\begin{array}{c}\text { Thermal Energy, } \\
\text { thnd. MW/mln } \\
\text { Euro }\end{array}$ & $\begin{array}{l}\text { Fuel, thnd. } \\
\text { tons/mln Euro }\end{array}$ & & \\
\hline Oil and gas production & $37,000 / 1665.4$ & $321,280 / 89.06$ & $1547 / 43.16$ & $7093 / 1797.63$ & 37.4 \\
\hline Oil refining & $6001 / 248.3$ & $22,632 / 247.57$ & $4093 / 15,529$ & $9786 / 689.97$ & 51.6 \\
\hline $\begin{array}{l}\text { Petroleum chemistry } \\
\text { and gas refining }\end{array}$ & $23,000 / 79.2$ & $7907 / 70.05$ & $405 / 14.63$ & $1843 / 163.86$ & 9.7 \\
\hline $\begin{array}{l}\text { Gas production } \\
\text { and distribution }\end{array}$ & $340 / 1746$ & $131 / 3.3$ & $61 / 1.27$ & $142 / 26.4$ & 0.7 \\
\hline Oil products supply & $319 / 20.9$ & $81 / 1.07$ & $5 / 0.4$ & $55 / 22.4$ & 0.3 \\
\hline Service & $92 / 5.65$ & $288 / 5.63$ & $2 / 0.26$ & $48 / 11.53$ & 0.4 \\
\hline In total & $46,800 / 2041.3$ & $34,241 / 416.7$ & $6111 / 253.83$ & $18,967 / 2711.82$ & 100.0 \\
\hline
\end{tabular}

In the energy-saving program of PJSC Rosneft for 2021-2024 it is planned to carry out the measures to increase the efficiency of use of electric and thermal energy by main areas of production activities. The actual saving of FER for the year 2020 is shown in Table 2 [26].

Table 2. Actual saving of fuel and energy resources for 2020.

\begin{tabular}{|c|c|c|c|c|c|}
\hline \multirow[b]{2}{*}{ Area of Activity } & \multicolumn{3}{|c|}{ Saving of Resources in 2020} & \multirow{2}{*}{$\begin{array}{l}\text { Adjusted } \\
\text { to thnd. Tons of } \\
\text { Fuel Equivalent }\end{array}$} & \multirow[b]{2}{*}{ Share, $\%$} \\
\hline & $\begin{array}{c}\text { Electric Energy, } \\
\text { MWh }\end{array}$ & $\begin{array}{c}\text { Thermal Energy, } \\
\text { MW }\end{array}$ & $\begin{array}{c}\text { Fuel, } \\
\text { thnd. Tons }\end{array}$ & & \\
\hline Oil and gas production & 1356 & 2.3 & 957 & 164.1 & 41.0 \\
\hline Oil refining & 33.65 & 275 & 175,129 & 212.2 & 54.0 \\
\hline Petroleum chemistry & 3458 & 46 & 9373 & 15.3 & 4.0 \\
\hline Gas distribution & 26.93 & 0 & 0 & 3.2 & 0.8 \\
\hline Oil products supply & 4.61 & 0 & 144 & 0.7 & 0.2 \\
\hline Internal service & 1.55 & 1.63 & 365 & 0.7 & 0.2 \\
\hline In total & 1427 & 325 & 185,967 & 396.3 & 100.0 \\
\hline
\end{tabular}

According to the policy of Rosneft, aimed at improvement of energy efficiency and energy saving, and the company's standard "Energy management system. Requirements and guideline for use", the next measures were taken in 2020 [25,26]:

- the regulations for work with the module "Energy efficiency of electric submersible pump units" of the information system "Mekhfond" were developed. Firstly, this has allowed introduction of the control procedure of energy efficiency of electric submersible pump units in the process of exploitation of producing wells. Secondly, it has allowed carrying out energy saving measures over time, without equipment failures or loss of geotechnical jobs;

- the process of corporate training with five energy efficiency courses was organized. In 2020, 471 employees finished studying;

- $\quad$ order No. 71 of PJSC Rosneft "On the development and implementation of targeted programs for the implementation of an information system for monitoring energy consumption at oil refining and petrochemical enterprises", dated 3 February 2020 was put into effect. This order involves formation of an automated instrument base for accounting of fuel and energy resources and the creation/implementation of corporate software for regulation, planning and reporting of energy consumption; 
- corporate check of energy management system of "Exploration and production" business unit was carried out. Individual roadmaps to achieve an improvement of detected disadvantages were prepared;

- an internal audit of energy efficiency of 386 technological objects and units was carried out by its own personnel-energy-saving and energy efficiency departments, in order to find the potential of energy saving and its implementation in terms of the energysaving program;

- 42 enterprises of the company were certified to the ISO 50001 "Energy management system".

Selection of optimal well operation methods is one of the main technological tasks of oil recovery by means of an artificial lift. Specific energy consumption can be adequately assessed by means of control, on the basis of which accurate calculations can be undertaken, determining the economic, technical and technological features of the operation method for a particular well [27-32].

The main directions to increase energy efficiency of the operation of the artificial lift well stock are:

Technical measures:

- $\quad$ implementation of energy-saving design of electric submersible pump units (ESPU);

- $\quad$ using the pumps and submersible motors with better technical characteristics, than standard ones;

- $\quad$ replacement of the ESPU model range and the creation of a high depression due to high heads and great depths;

- comparison of ECE of ESP of different standard sizes, produced by different manufacturers;

- $\quad$ replacement of ESPU by sucker-rod pumping units (SRPU);

- implementation of dual action sucker-rod pumps;

- implementation of intelligent control stations for SRPU;

- $\quad$ shifting low flow rate wells to screw pump operation;

- implementation of plastic rods or light metal rods;

- $\quad$ use of submersible cables of bigger diameter;

- cable heating;

- decreasing the load on;

- $\quad$ transition from using asynchronous submersible electric motors to submersible AC electric motors

- impeller trimming;

- cascade regulation in case of parallel installation of pumps;

- decreasing rotation rate of pump under constant parameters of electric power network;

- $\quad$ using nano-coatings for impellers of ESP;

- creation of installations for simultaneously-separate exploitation;

- $\quad$ use of chain drive;

- $\quad$ replacement of power stations with diesel motors by the more energy efficient onesgas turbine motors;

- $\quad$ operation of submersible equipment in periodic modes;

- $\quad$ decrease in produced water and its injection in strata (shutdown of low-profit well stock and conducting geotechnical works);

- $\quad$ selection of optimal standard size and replacement of pump aggregates on cluster pump stations, booster pump stations and preliminary water separation units;

- $\quad$ installation of variable speed drives on pumping equipment;

- $\quad$ reducing losses in electric power grids.

Technological measures:

- controlling the operation parameters of each well in real time mode with an access to the upper level of automatic control systems of technological parameters (ACS TP);

- $\quad$ completing control stations with individual certified electric power meters, one for each working well or newly introduced one; 
- possibility to monitor technological parameters behavior in time, including work current, voltage, inlet pressure, temperature of submersible electric drive, dynamic fluid level, energy consumption and etc. on each well.

Organizational measures:

- creation of an organizational structure at the enterprise that has the authority to effectively solve problems in the field of reducing energy consumption. Its functioning is based on the involvement of the maximum number of specialists in the process of saving energy, starting with the shop personnel and ending with the top managers of the enterprise, with an incentive to achieve the final result, a clear delineation of areas of responsibility;

- $\quad$ training of corporate specialists with receiving a certificate for carrying out internal audits of energy management system in accordance with the requirements of international standard ISO 50001.

The volumes of electric energy consumption in OJSC "Udmurtneft"- Rosneft Group subsidiary: artificial lift- $55 \%$, water injection-36\%, oil treatment and transport- $6 \%$, other production needs-3\%, general and administrative expenses-1\% [26].

For calculation and control of energy efficiency, specific energy consumption (SEC) was selected as the main parameter. Specific energy consumption reflects energy output ratio with actual/planned parameters of electric energy consumption on the artificial lift of fluid and fulfillment of geotechnical works.

Methodology of energy planning consists of the following:

The first (base) year-actual SEC is calculated, geological and technical factors are taken into account and analyzed.

The second year-the program of energy-saving measures is formed for the calculation period, economy of energy is calculated.

The third year-having taken geological and technical factors into account, the planned value of SEC is set.

On the basis of the results, the deviation of actual values from the planned ones is analyzed and SEC is corrected.

The energy saving program of enterprises of PJSC "Rosneft" demonstrates economy of electric energy: 27,000 MWh for 80.5 million rubles. (OJSC "Udmurtneft") and 52,860 MWh in JSC "Samotlorneftegaz" (Figures 2 and 3) [25,26,33].

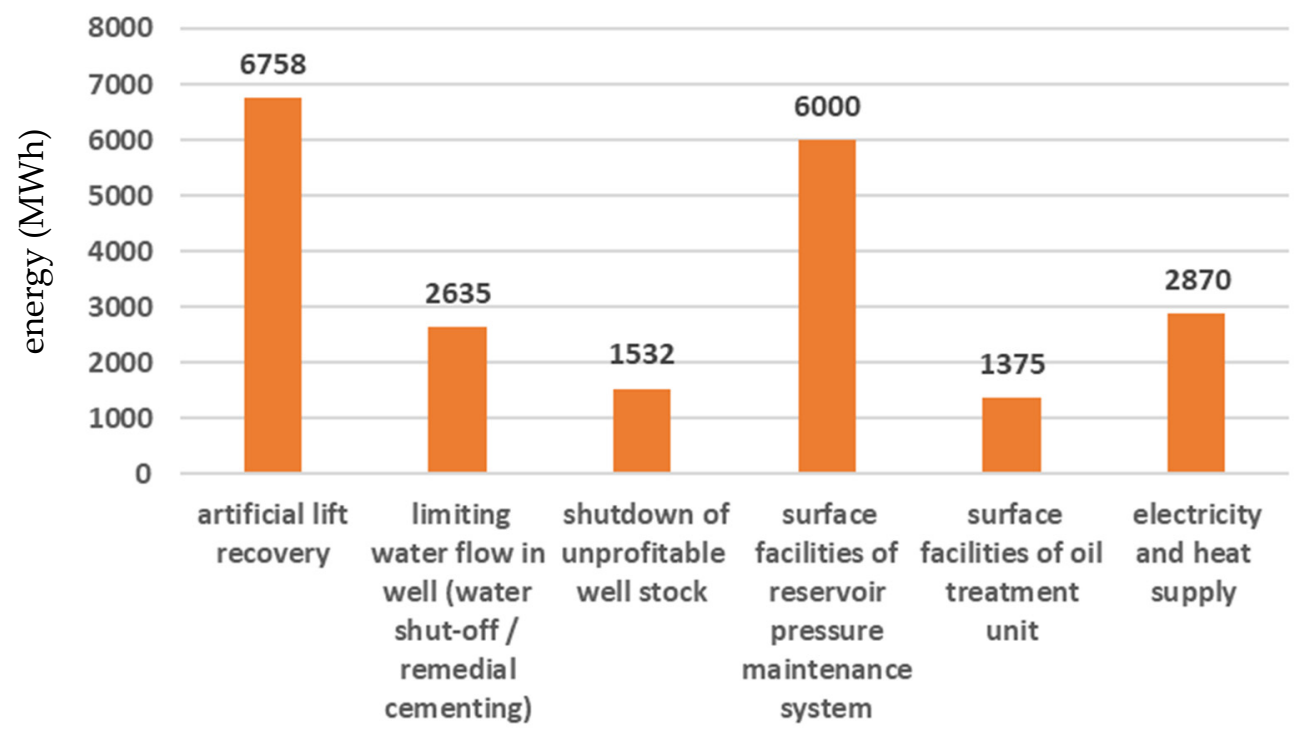

Figure 2. Energy saving structure of OJSC "Udmurtneft". 


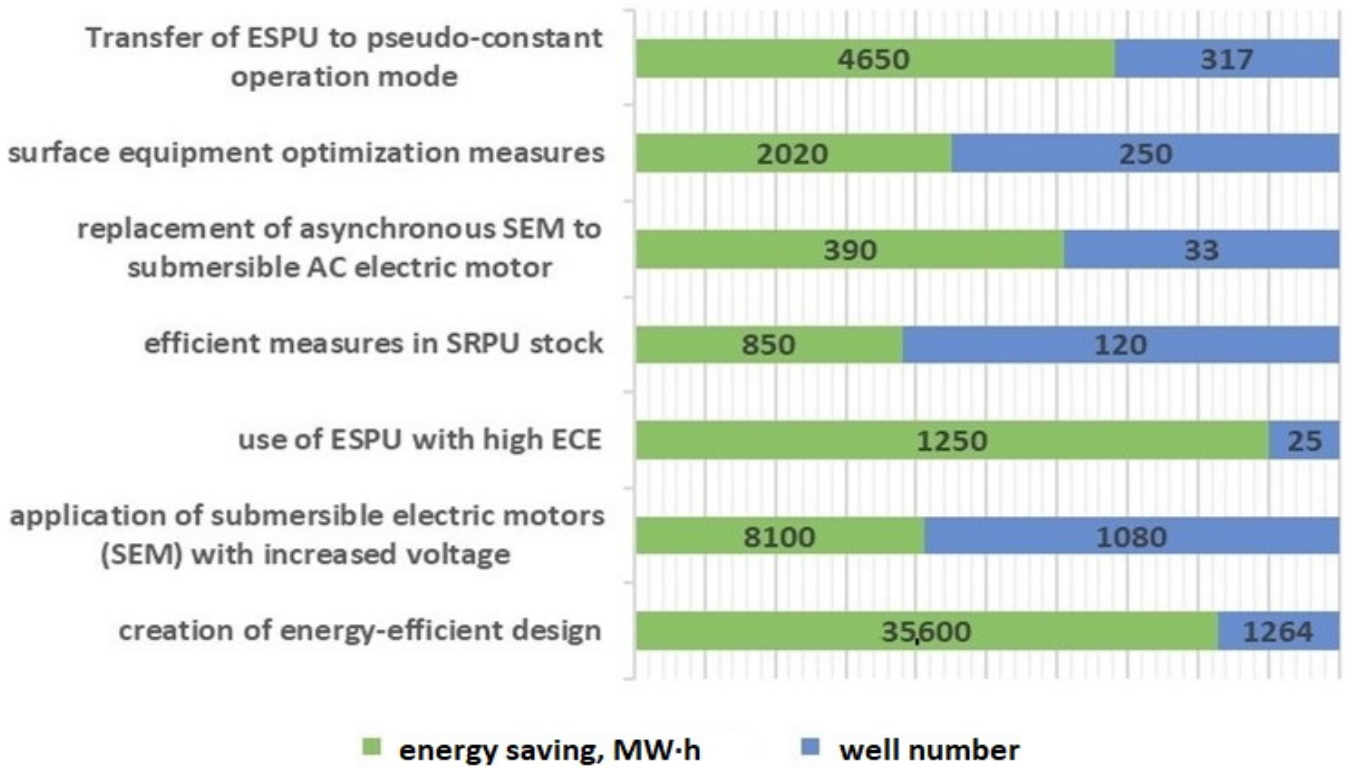

Figure 3. Analysis of the conducted energy efficient measures on the artificial lift well stock in JSC "Samotlorneftegaz".

According to Gazprom Neft, electricity savings in the exploration and production unit reached 2850 MWh in 2020, reducing energy costs by approximately 8.87 million euros [33].

The fulfilled analysis of artificial lift well stock has allowed us to develop energysaving measures and show the results from their implementation (Table 3).

Table 3. Directions of energy saving and increasing energy efficiency in oil production.

\begin{tabular}{|c|c|}
\hline Energy-Saving Measures & Results from Implementation \\
\hline $\begin{array}{l}\text { - Production and injection well stock management } \\
\text { - Limited water injection } \\
\text { - Bottom-hole zone treatment } \\
\text { - Fulfillment of remedial cementing works in wells }\end{array}$ & $\begin{array}{l}\text { - Decreasing variable part of costs on: } \\
\text { electric energy on lifting fluid from the } \\
\text { reservoir, oil gathering and transport, } \\
\text { maintenance and operation of equipment, } \\
\text { reservoir pressure maintenance; } \\
\text { - Possibility to reduce capital expenses; } \\
\text { - Decreased amount of produced fluid; reduced } \\
\text { oil production; decreased variable cost, which } \\
\text { depend on volume of the produced fluid; } \\
\text { reducedcosts on consumed energy }\end{array}$ \\
\hline Use of modern ESPU with increased ECE & $\begin{array}{l}\text { - Decrease in energy consumption and costs } \\
\text { on energy; } \\
\text { - Increase in mean-time-between-repairs }\end{array}$ \\
\hline $\begin{array}{l}\text { - Replacing power transformers with a higher } \\
\text { power by lower ones; } \\
\text { - Reconstruction of grids, replacement of } \\
\text { cross-sections, material, length; } \\
\text { - Replacement of asynchronous motors } \\
\text { - Replacement of high-power pumps by } \\
\text { lower-poer pumps; } \\
\text { - Accounting heat energy }\end{array}$ & $\begin{array}{l}\text { - Reduced payment for the electricity } \\
\text { component; } \\
\text { - Decreased energy costs- Economy of heat } \\
\text { and decreased costs on heat energy; } \\
\text { - Increased profit due to reduced } \\
\text { operation costs }\end{array}$ \\
\hline
\end{tabular}

The whole complex of described measures has allowed us to achieve excellent results in the area of energy efficiency improvement. Energy saving on fields of Udmurtia has increased from $15 \%$ to $43 \%$, and specific consumption of energy for fluid lifting has been reduced by $2-4$ times. 
In today's situation, energy efficiency is increased by means of implementation of technologies with minimal investments. Most low-cost technologies with high economic indicators have low technological efficiency with limited application possibilities and are able to reduce energy consumption by up to $10 \%$. To achieve a significant effect, it is required to widely introduce the technologies that have both high technological and economic efficiency. However, there is a potential for optimization.

\section{Results}

All in all, the approach of Russian oil-production enterprises to the formulation of energy policy can be assessed as a strategy of implementation of all investment-attractive measures. The analysis of studies has allowed us to determine the main constraints to implementation of a policy of increasing the energy efficiency at oil-production enterprises and propose the main ways to improve the organization of energy saving (Figure 4).

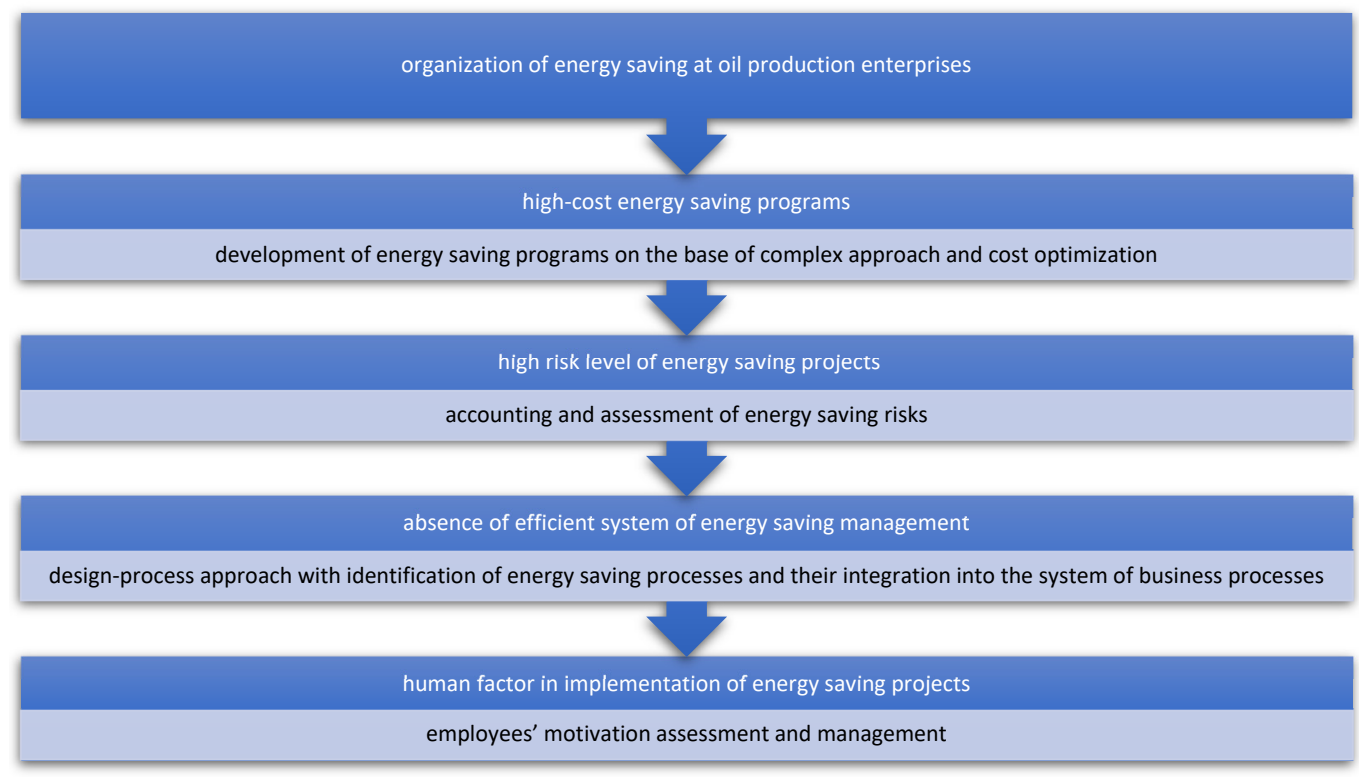

Figure 4. Constraints and ways of improvement of organization of energy saving at oilproduction enterprises.

Proposed methodological support for improvement of the energy management system and measures that are used for development of the organizational mechanism of energy saving management at oil production enterprise are shown in Table 4.

Table 4. Measures aimed at improvement of energy management system.

\begin{tabular}{|c|c|c|c|}
\hline Strategic Measure Type & Degree of Changes & Payback Period & Capital Investment Level \\
\hline Information system improvement & $\begin{array}{l}\text { Affects all units of an } \\
\text { enterprise }\end{array}$ & Long, about $3-5$ years & $\begin{array}{l}\text { high or medium depending on } \\
\text { complexity of the system being } \\
\text { implemented and level of monitoring }\end{array}$ \\
\hline $\begin{array}{l}\text { Staff training in the field of } \\
\text { efficient use of energy sources }\end{array}$ & $\begin{array}{l}\text { Affects all units of an } \\
\text { enterprise }\end{array}$ & $\begin{array}{l}\text { Long, can be determined by } \\
\text { indirect methods due to the } \\
\text { economic effects of energy saving }\end{array}$ & high, investment level is relatively low \\
\hline $\begin{array}{c}\text { Implementation of technical and } \\
\text { technological energy-saving } \\
\text { solutions }\end{array}$ & $\begin{array}{l}\text { Specific industrial processes } \\
\text { and units, nonsystematic kind }\end{array}$ & $\begin{array}{l}\text { Medium, depends on source of } \\
\text { technologies-whether they are } \\
\text { purchased or made by } \\
\text { internal innovations }\end{array}$ & $\begin{array}{l}\text { medium, it does not excess costs on } \\
\text { buying more energy efficient } \\
\text { equipment of similar purpose }\end{array}$ \\
\hline $\begin{array}{l}\text { System technologies of energy } \\
\text { saving, also affect non-production } \\
\text { units, attraction of alternative } \\
\text { sources of energy saving }\end{array}$ & $\begin{array}{l}\text { Affects all units of an } \\
\text { enterprise }\end{array}$ & Long, about $10-15$ years & low, huge investments are needed \\
\hline
\end{tabular}


Table 4 shows the generalized classification of measures, technical and economic indicators of efficiency of energy-saving on a strategic level that should be implemented by oil-production enterprises in the energy-saving sphere.

The following scheme is proposed for the formation of energy saving programs (Figure 5).

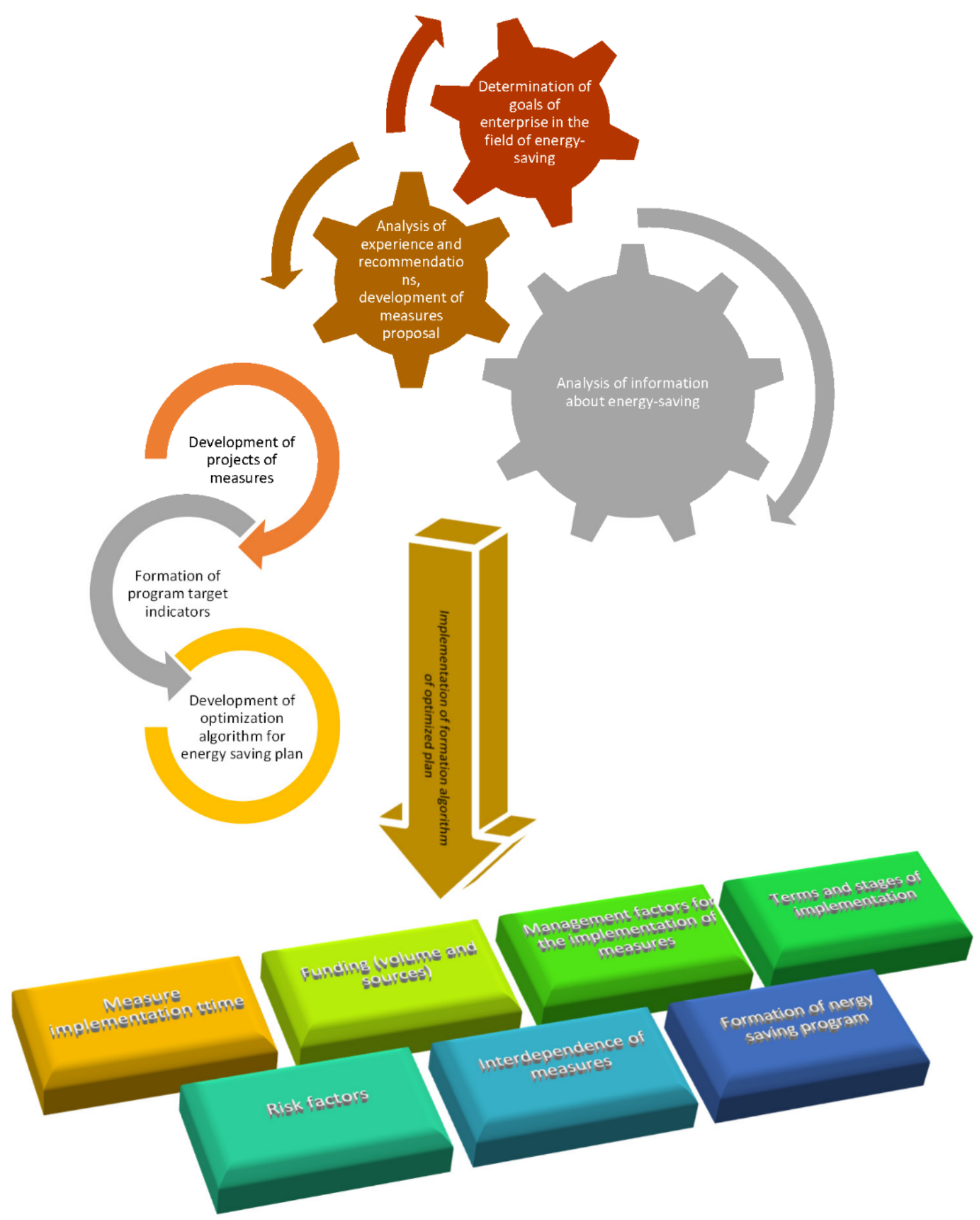

Figure 5. Scheme of formation mechanism of energy-saving programs at an oil-production enterprise. 
The energy efficiency indicators of the organization of production include the specific energy intensity of the production space:

$$
E=\frac{Q}{S}
$$

where $E$-specific energy intensity of the production space, $\mathrm{GJ} / \mathrm{m}^{2}$;

$Q$-amount of energy spent to support activities of industrial unit, GJ (or $\mathrm{kW} \cdot \mathrm{h}$ );

$S$-area of industrial unit, $\mathrm{m}^{2}$.

Key energy efficiency indicators include:

- $\quad$ share of use of secondary thermal energy in the main and auxiliary production;

- growth of fuel combustion heat, intensification of fuel use;

- $\quad$ specific energy consumption per year;

- $\quad$ share of energy costs in prime cost of production (energy intensity);

- $\quad$ reduction of emission;

- $\quad$ average energy consumption per crew per shift;

- $\quad$ efficiency of investment into internal energy projects, aimed at energy saving;

- $\quad$ implementation of technological innovations in energy saving.

\section{Conclusions}

For oil-producing enterprises, the issues of optimizing energy costs are among priorities, since the economic profitability of an enterprise greatly depends on how efficiently energy resources are spent. One of the most effective mechanisms are the implementation of energy-saving technologies and an increase in the energy efficiency of the artificial lift of oil.

Relevant scientific results include the following:

1. The main constraints on the implementation of the energy efficiency policy at oilproducing enterprises have been identified and directions for improvement of energysaving structures have been proposed.

2. We have proposed strategic-level classification of energy-saving measures, which is based on assessment and comparison of implementation costs, payback period and takes into account investments into artificial lift technology, thereby allowing us to discern the investment priorities in the energy management sphere.

3. Advanced directions for investment in oil-production technology have been identified, and an algorithm for development and implementation of key indicators of energy consumption efficiency has been proposed.

The proposed directions of energy saving and energy efficiency improvement for oil production promise to have a great economic impact. Analysis of results shows that the effect from implementation of the organizational mechanism of energy saving management at one enterprise from energy policy reached 40 million rubles over three years.

Author Contributions: Conceptualization, T.N.I. and O.V.Z.; methodology, T.N.I.; validation, K.M., W.B. and M.M.; formal analysis, W.B.; investigation, O.V.Z.; resources, T.N.I.; data curation, O.V.Z.; writing—original draft preparation, T.N.I.; writing—review and editing, K.M. and W.B.; visualization, T.N.I.; supervision, W.B.; project administration, M.M.; funding acquisition, W.B., K.M. and M.M. All authors have read and agreed to the published version of the manuscript.

Funding: This research was funded by Silesian University of Technology [Poland] and KOMAG Institute of Mining Technology [Poland].

Institutional Review Board Statement: Not applicable.

Informed Consent Statement: Not applicable.

Data Availability Statement: Data available in a publicly accessible repository that does not issue DOIs. Publicly available datasets were analyzed in this study. This data can be found here: https:/ / www.rosneft.ru/docs/report/2020/en/results.html (accessed on 27 December 2021).

Conflicts of Interest: The authors declare no conflict of interest. 


\section{Nomenclature}

PDCA
SEC
FER
ESPU
ECP
SRPU
ACS TP
ESPU with increased ECE

\author{
"Plan-Do-Check-Act" \\ specific energy consumption \\ fuel and energy resources \\ electric submersible pump units \\ electric centrifugal pump \\ sucker-rod pumping units \\ automatic control systems of technological parameters \\ electric centrifugal pump with increased efficiency
}

\section{References}

1. Hronika OON. Available online: https://www.un.org/ru/issues/ustoychivaya-energetika (accessed on 21 January 2021).

2. Fuchs, H.; Aghajanzadeh, A.; Therkelsen, P. Identification of Drivers, Benefits, and Challenges of ISO 50001 through Case Study Content Analysis. Energy Policy 2020, 142, 111443. [CrossRef]

3. Marimon, F.; Casadesús, M. Reasons to Adopt ISO 50001 Energy Management System. Sustainability 2017, 9, 1740. [CrossRef]

4. Gonçalves, V.A.D.S.; Dos Santos, F.J.M. Energy Management System ISO 50001:2011 and Energy Management for Sustainable Development. Energy Policy 2019, 133, 110868. [CrossRef]

5. Poveda-Orjuela, P.P.; García-Díaz, J.C.; Pulido-Rojano, A.; Cañón-Zabala, G. ISO 50001: 2018 and Its Application in a Comprehensive Management System with an Energy-Performance Focus. Energies 2019, 12, 4700. [CrossRef]

6. Rampasso, I.S.; Filho, G.P.M.; Anholon, R.; de Araujo, R.A.; Lima, G.B.A.; Zotes, L.P.; Filho, W.L. Challenges Presented in the Implementation of Sustainable Energy Management via ISO 50001:2011. Sustainability 2019, 11, 6321. [CrossRef]

7. Mkhaimer, L.G.; Arafeh, M.; Sakhrieh, A.H. Effective Implementation of ISO 50001 Energy Management System. Int. J. Eng. Bus. Manag. 2017, 9, 1847979017698712. [CrossRef]

8. Zimoch, I.; Bartkiewicz, E.; Machnik-Słomka, J.; Kłosok-Bazan, I.; Rak, A.; Rusek, S. Sustainable water supply systems management for energy efficiency: A case study. Energies 2021, 14, 5101. [CrossRef]

9. Kanneganti, H.; Gopalakrishnan, B.; Crowe, E.; Al-Shebeeb, O.; Yelamanchi, T.; Nimbarte, A.; Currie, K.; Abolhassani, A Specification of Energy Assessment Methodologies to Satisfy ISO 50001 Energy Management Standard. Sustain. Energy Technol. Assess. 2017, 23, 121-135. [CrossRef]

10. Rotzek, J.N.; Scope, C.; Günther, E. What Energy Management Practice Can Learn from Research on Energy Culture? Sustain. Account. Manag. Policy J. 2018, 9, 515-551. [CrossRef]

11. Standard ISO 50001:2018 Energy Management System. Available online: https://www.iso.org/iso-50001-energy-management. html (accessed on 1 August 2021).

12. Riche, J.P. LeanergyTM: How Lean Manufacturing Can Improve Energy Efficiency. Chimia 2013, 67, 700-702. [CrossRef] [PubMed]

13. Savenok, O.V. Development of Oil and Gas Fields; KubSTU: Krasnodar, Russia, 2019; Available online: https://e.lanbook.com/ book/151189 (accessed on 25 June 2021).

14. Popov, I.P. New Technologies in Oil and Gas Geology and Field Development; Lan: St. Petersburg, Russia, 2021; Available online: https:/ /e.lanbook.com/book/174975 (accessed on 5 March 2021).

15. Lukyanov, V.G.; Krets, V.G. Mining Machines and Mining Exploration Workings; Yurayt Publishing House: Moscow, Russia, 2021; 342p, Available online: https:/ / urait.ru/bcode/470908 (accessed on 9 February 2021).

16. Khakimzyanov, I.N.; Khisamov, R.S.; Bakirov, I.M. Issues of Optimization and Efficiency Improvement of Wells with Horizontal Completion Based on Mathematical Modeling of Tatarstan Fields; OJSC VNIIOENG: Moscow, Russia, 2014.

17. Trubetskoy, K.N.; Galchenko, Y.P.; Kalabin, G.V.; Proshlyakov, A.N. Environmental Problems of Geotechnology in the Development of the Mineral Resource Complex of the Arctic; Ltd Nauchtehlitizdat: Moscow, Russia, 2018.

18. Kislitsyn, A.A. (Ed.) Theory of Heat and Mass Transfer in Oil and Gas and Construction Technologies; Yurayt: Moscow, Russia, 2021; Available online: https:/ / urait.ru/bcode/472381 (accessed on 28 April 2021).

19. Galchenko, Y.P.; Sabyanin, G.V. Problems of Geotechnology of Vein Deposits; Ltd Nauchtehlitizdat: Moscow, Russia, 2011.

20. Vasiliev, V.A. Management of the Development of Intelligent Deposits; Lan: Stavropol, Russia, 2015; Available online: https://e. lanbook.com/book/155184 (accessed on 19 February 2021).

21. Viktorov, S.D.; Galchenko, Y.P.; Zakalinsky, V.M. Explosive Destruction of Rocks in the Development of Complex-Structured Deposits; Ltd Nauchtehlitizdat: Moscow, Russia, 2013.

22. Jabbour, A.B.L.D.S.; Júnior, S.A.V.; Jabbour, C.J.C.; Filho, W.L.; Campos, L.S.; de Castro, R. Toward Greener Supply Chains: Is There a Role for the New ISO 50001 Approach to Energy and Carbon Management? Energy Effic. 2017, 10, 777-785. [CrossRef]

23. Kals, J. Betriebliches Energiemanagement-Eine Einführung; Kohlhammer: Stuttgart, Germany, 2010.

24. Vakhitov, G.G. Oil Industry of Russia: Yesterday, Today, Tomorrow: Experience in the Development of Hydrocarbon Deposits in 1950-2012; OJSC VNIIOENG: Moscow, Russia, 2012.

25. Obrashcheniye Predsedatelya Soveta Direktorov Pao «NK ROSNEFT'». Available online: https://www.rosneft.ru/docs/report/ 2020/ru/company.html (accessed on 15 April 2021). 
26. Povysheniye Energoeffektivnosti pri Mekhanizirovannoy Dobyche Nefti. Available online: https://www.rosneft.ru/upload/ site1/document_publication/177209/attach_3-2014.pdf (accessed on 18 January 2021).

27. Scientific and Technical Bulletin of «Rosneft»; OJSC NK Rosneft: Moscow, Russia, No. 3. 2014. Available online: https: //www.rosneft.ru/upload/site1/document_publication/177207/v03-2014.pdf (accessed on 15 May 2021).

28. Ivanovsky, V.N. Power Engineering of Well Operation by Artificial Lift Methods, Choice of Operation Method, Ways to Improve Energy Efficiency. Eng. Pract. 2010, No 3. Available online: https:/ / glavteh.ru/ (accessed on 25 May 2021).

29. Lysenko, O.A.; Simakov, A.V.; Gorovoy, S.A. Improving the energy efficiency of pumping units in the oil refining industry. Omsk Sci. Bull. 2018, 6. [CrossRef]

30. Wan, J.; Li, J.; Hua, Q.; Celesti, A.; Wang, Z. Intelligent equipment design assisted by Cognitive Internet of Things and industrial big data. Neural Comput. Appl. 2020, 32, 4463-4472. [CrossRef]

31. Kuang, L.; Liu, H.; Ren, Y.; Lou, K.; Shi, M.; Su, J.; Li, X. Application and development trend of artificial intelligence in petroleum exploration and development. Pet. Explor. Dev. 2021, 48, 1-14. [CrossRef]

32. Dong, L.; Sun, D.; Han, G.; Li, X.; Hu, Q.; Shu, L. Velocity-Free Localization of Autonomous Driverless Vehicles in Underground Intelligent Mines. IEEE Trans. Veh. Technol. 2020, 69, 9292-9303. [CrossRef]

33. Ivanova, T.N.; Baranov, M.N.; Gubanov, A.M.; Novokshonov, D.N. Design and Technological Support for Methods of SimultaneousSeparate Operation of Multilayer Objects of Fields: Monograph; Publishing House: Krasnodar, Russia, 2020. 